\title{
Research on the Development of the Resources of Folk Arts and Crafts of Northeastern Jiangxi Province in the Course of Environmental Design in Colleges and Universities
}

\author{
Cui Dong ${ }^{1, a}$ \\ ${ }^{1}$ School of Art and Design, Jingdezhen Ceramic Institute, Jingdezhen ,China \\ aaminy530@163.com
}

\begin{abstract}
Keywords: the resources of folk arts and crafts ,northeastern jiangxi province, the course of environmental design, course development.

Abstract. The resources of traditional folk arts and crafts have distinct regional and essential features, which are defined as a treasure house of visual art in modern design. A case study of folk arts and crafts in the northeast of Jiangxi province is made in this paper, which has sorted out the present situation of folk art resources in northeastern Jiangxi province, analyzed the necessity of the integration of folk arts and crafts resources of the northeast of Jiangxi province into the design teaching of colleges and universities. Finally, the development method of the folk arts resources of the northeast of Jiangxi province in the environment design course of the colleges and universities is proposed, so as to realize the inheritance of Chinese folk arts and crafts in the environmental space with cultural characteristics.
\end{abstract}

\section{Introduction}

Chinese folk arts and crafts have a long history, of which the cultural heritage is rich, the style is unique, which imply a profound cultural background and enjoy high reputation both at domestic and abroad, therefore, how to combine the traditional culture with the modern design and development is an urgent problem to be solved in our country's folk arts. This paper takes the folk arts and crafts in the northeast of Jiangxi province as an example, which is aimed at how to better integrate the resources of folk arts and crafts in the environmental design subject of colleges and universities, which is not only conducive to the living state inheritance of folk arts and crafts, but also more conducive to promoting the development of college design subject and the consciously inheritance of students to traditional culture.

\section{Present situation of folk arts and crafts resources in northeast Jiangxi province}

Chinese craftsmen and folk artists obtain raw materials locally to create folk art works with regional characteristics by virtue of their abilities and cleverness, and skills with great originality. Northeastern Jiangxi province, including such three prefecture level cities as Jingdezhen, Shangrao and Yingtan in the northeast of Jiangxi province, such region has the most abundant cultural diversity in Jiangxi province. In addition to the culture of Jiangxi, the $\mathrm{Wu}$ Yue culture, Hui culture are also the local cultures here, which make the rich folk art resources in northeastern Jiangxi, and the colorful forms. According to the regional perspective, the resources of folk fine arts resources in the northeast of Jiangxi province are distributed in many districts and counties, including the famous folk ceramic art with decoration and practicality in Jingdezhen area, the three-carving art deeply affected by Huizhou culture--brick carving, stone carving and wood carving, which are widely used in antique furniture, garden and building decoration. In addition, including the local bamboo art, root carving, Jialu umbrella (made of oiled paper and bamboo frame), and the chrismatite carving in Yingtan area, etc. Among these excellent and rich folk arts and crafts in northeastern Jiangxi province, in addition to a better inheritance to ceramic art, the traditional bearers to other folk arts are very scarce. Folk arts are generally taught to the apprentices by experienced artists, however, due to the more time-consuming of works of crafts, and under the modern fast rhythm of life, young people who can adhere to the learning of arts are rare, this causes these experienced artists to tend to be aging, marginalized, which means 
traditional handicraft is on the verge of extinction, therefore, it is of great significance to inherit and carry forward the folk arts of our country among young people, especially the college students.

\section{The necessity of the integration of folk arts and crafts resources of northeastern Jiangxi province into the teaching of environmental design in colleges and universities}

Promoting the inheritance and development of traditional folk arts and crafts in our country by using the platform of colleges and universities. Regional culture refers to the unique cultural tradition of long standing and well established, which still plays a role since it being inherited so far, the focus and promotion of regional culture is the persistent mission of us. Under the condition of traditional cultural value orientation influenced by contemporary thought, local colleges and universities are the direct spreading land of folk arts and crafts. To guide students to correctly understand the cultural and artistic value of Chinese folk arts and crafts through university platform, and to draw nourishment from local folk arts and crafts can enable them know how to cherish the precious cultural heritage, understand the importance of inheriting and developing the excellent national cultural heritage, which will play a role in promoting the inheritance of Chinese arts and crafts, and the improvement of design teaching. Inheritance and innovation based on folk arts and crafts, finding the conjunction point of environmental art design and local folk arts and crafts, and exploring the principles and methods of folk arts and crafts used by modern environmental art design, which is also a way to explore the distribution of national and regional characteristics of modern environmental art design.

Stimulating the interest of the young generation to the intangible cultural heritage of our country, improving students' design creativity. Specific geographical and cultural environment, historical heritage, folk arts and crafts are closely linked, different natural and cultural ecological environments cultivate unique folk arts and crafts styles and categories, which provide inexhaustible visual art elements for modern art and design. "Only when it is national, it is world", the folk art is rooted in the folk, with strong national characteristics. Only the people who have been nourished by the national culture will conceive confidence in the nation, and spontaneously integrate the national culture into the design work. Local arts and crafts resources are excellent design language, the exploration of theory teaching and practice by utilizing the resources of folk arts and crafts in northeast Jiangxi in the environmental design professional course to integrate folk arts and crafts in northeast Jiangxi into classroom will enable students to integrate into the context of China's folk culture, understand the traditional culture, so as not only to cultivate the students' love of folk art tradition, enrich students' feelings, but also be conducive to broaden the students' thinking, enhance students' ability of modeling and application ability of language design. The excellent resources of local folk arts and crafts are widely absorbed in the course, and the regional folk arts and crafts resources are integrated with environmental design teaching in colleges and universities, which is of great significance to improve the students' professional ability.

Enriching the forms of folk arts and crafts education, and forming the consciousness of the whole people to protect the folk arts. The folk arts and crafts in northeast Jiangxi is a typical representative of the original ecological culture in Jiangxi, rooted in the folk, simple and dignified, containing the special content of regional culture and the spirit of humanism, however, years of occlusion and poverty have caused a lot of folk arts and crafts gradually lost. One of the important reasons is the lack of protection awareness of the whole people, many experts and scholars strongly have appealed the importance of inheriting folk arts, but the whole people's awareness of protection has not been mobilized. It will help to inspire people's sense of pride, and produce the responsibility to protect the folk arts through the popularization of folk arts and crafts in the design of colleges and universities to make the folk arts and crafts diversified in form and promote the development of folk art education. 
The development method of folk arts and crafts resources of northeastern Jiangxi province in the course of environmental design in colleges and universities

Refining the resources of folk arts and crafts in northeast Jiangxi, and integrating it into the theory course of environmental design. The distribution range of folk arts and crafts in northeast Jiangxi is wide, and the forms are diversified, the most significance to integrate them into the course of environmental design is the collection and extraction of arts and crafts resources. This requires teachers to strengthen their knowledge reserve of folk arts and crafts in the northeast of Jiangxi province, and extract resources available for design practice from such aspects as shape, color, pattern, decoration, cultural symbol and so on, and elaborated design teaching links, adopting multimedia picture display, animation demo, model analysis and other ways to directly explain these folk arts and crafts resources, so as to enable students to understand and recognize the basic concept of folk arts. On the one hand, the use of interior design, landscape design, architectural appearance design for exploration; on the other hand, directly or indirectly applying them to the basic courses (three major components, design graphics, etc.) and major courses (interior design series courses, environmental landscape design series courses, and architectural design) teaching process. For example, in the introduction of landscape sculpture works, teachers can directly quote Jingdezhen folk ceramic arts into the theoretical course to explain; when explaining the ancient architecture of China, some three-carving arts in Huizhou ancient architectures can be also quoted.

The integration of folk arts and crafts elements of northeast Jiangxi province in the design practice. The design practice link after the theoretical explanation is also required to integrate into the folk arts and crafts. Through students hands-on practice, to encourage students to learn the language of folk art and unique performance techniques, so as to implement the ingenious fusion of folk arts and crafts resources and environment art design subject between tradition and modernity. Some folk arts and crafts can be used directly, for example, for folk art works, they can be directly used as indoor furnishings or outdoor landscape sketches; but most of the folk arts and crafts are indirectly used after passing through the "post processing". Therefore, teachers can guide students to make a new combination through means of art and technique by exercises for special assignments, so as to achieve the requirements of "Extraction of its shape", "Extension of its meaning", and "Spreading of its verve". Exampled by the blue and white porcelain of Jingdezhen, in interior space design, the blue and white porcelain works can be applied to interior furnishings, and the extraction of its color and pattern can also be applied to the folding screen through three dimensional design, and placed in the study, entrance, which can give people a kind of antique flavor. The three-carving art of Wuyuan can be used into indoor carving, screen decoration, which can give people a comfortable, comfortable experience with its beauty of lines and unique dependable sense of woodcarving. The brick carving can be adopted to garden design, which can play a role of keeping out sights from outside and preventing leakage of privacy. Such techniques of expression as quotation, exaggerating, transformation can be used for the combination of folk arts and modern designs in the space design of modern environment, so as to find a kind of art form that combines traditional aesthetics with modern life, and achieve the purpose of "making the past serve the present".

Encouraging students to visit and study outside the classroom. In the integrated teaching mode of folk arts and crafts course, a variety of teaching methods should be used. It is necessary to open folk art investigation, sketching practice, establish folk art practice base inside and outside the course, and employ folk artists or craftsmen to guide, teach folk skills, so as to guide students to appreciate the folk art. On the base of investigation, students can communicate with folk artists face to face, and directly observe the process of their production. Meanwhile, practice sketching can also be carried out in the base, a large number of northeastern Jiangxi folk arts and crafts are contained in Yaoli of Jingdezhen, Wuyuan at the border Anhui and Jiangxi. Investigation and sketching on these rich and colorful folk arts resources will give students a great touch, so that they can better understand the connotation of folk arts and crafts, which will create a subtle influence on their design. 


\section{Conclusion}

The integration of folk arts and crafts in the teaching of environmental design in colleges and universities can combine the protection and inheritance to modern design and folk art on the one hand, so as to make the traditional folk arts play its due value and function in the contemporary environment design space; on the other hand, it can also precipitate students to understand the connotation and characteristics of traditional folk arts deeply, and enrich their design language of traditional folk arts, so that their recognition and conscious inheritance to national ethos and Chinese folk art culture can be cultivated.

\section{Acknowledgements}

This work was financially supported by the Teaching Reform Project of Higher Education in Jiangxi Province in 2015(No.JXJG-15-11-12).

\section{References}

[1] Zuo Hanzhong: The modeling of Chinese traditional folk art resources, the Artistic Press in Changsha, 2008.

[2] Fan Qi , Gong Gong: The watching of the technical and artistic works in modeling china, Technical and Artistic Press in Beijing, 2005.

[3] Li Longsheng: Heritage and innovation, Aesthetics and Age, 2002.(6):13-14 .

[4] Xin Linlin: The inheritance and development of folk art in the art education of local colleges and Universities, Big Stage, 2010.(10):190-191. 